\title{
POMOC PUBLICZNA JAKO ŹRÓDŁO FINANSOWANIA MŚP NA PRZYKŁADZIE WIELKOPOLSKI
}

Z a r y s t r e ś c i: Pomoc publiczna stanowi dziś bardzo ważne narzędzie finansowe pozwalające na urzeczywistnienie wielu zamierzeń inwestycyjnych MŚP. W artykule wykazano istnienie zależności pomiędzy zmianami wielkości przychodów, kosztów, zysków oraz wydatkami na środki trwałe, a faktem udzielenia pomocy publicznej przedsiębiorstwu. Dodatkowo ukazano zróżnicowanie w stopniu oddziaływania pomocy publicznej na beneficjentów w zależności od przynależności do określonej grupy wielkości przedsiębiorstw.

Słowa kluczowe: pomoc publiczna; dotacje, przychody; koszty; wydatki na środki trwałe.

K la s y fik a c ja J E L: G23.

\section{WSTĘP}

Przystąpienie Polski do Unii Europejskiej wywołało zainteresowanie pomocą publiczną kojarzoną przede wszystkim z dotacjami pochodzącymi ze środków funduszy europejskich. Jednakże pomoc publiczna znana była już wcześniej, dotyczyła między innymi subwencji podatkowych, związanych

\footnotetext{
* Adres do korespondencji: Michał Ginter, Uniwersytet Ekonomiczny w Poznaniu Wydział Zarządzania, Katedra Mikroekonomii, al. Niepodległości 10, 61-875 Poznań, e-mail: michal.ginter@ue.poznan.pl.
} 
z umarzaniem obowiązkowych obciążeń przedsiębiorstw [Famielec, 2007, s. 732].

Pomoc publiczna jest jedną z ważnych form ingerencji władz publicznych w gospodarkę i interwencjonizmu państwa. Udzielanie wsparcia niektórym podmiotom wiąże się z tworzeniem dla tych podmiotów lepszych warunków gospodarowania. Sposób udzielania pomocy publicznej wpływa na rozwój i wzrost społeczno-gospodarczy oraz na inne procesy i zjawiska zachodzące w gospodarce i życiu społecznym.

Celem artykułu jest ocena zależności występujących pomiędzy faktem udzielenia pomocy publicznej, a kształtowaniem się wartości przychodów, kosztów, zysków oraz wydatków na środki trwałe, a także ocena jej rozmiarów i wpływu na sytuację ekonomiczną przedsiębiorstw na przykładzie MŚP w województwie wielkopolskim. Analizie poddano wielkość i strukturę pomocy publicznej oraz wyniki ekonomiczne MŚP otrzymujących pomoc publiczną w Wielkopolsce w latach 2007-2012.

\section{POJĘCIE I ROLA POMOCY PUBLICZNEJ}

W literaturze przedmiotu zwraca się uwagę na brak wśród przepisów prawa europejskiego legalnej definicji pomocy publicznej. Brak takiej definicji nie stanowi jednakże przeoczenia prawodawcy europejskiego, lecz stanowi działanie świadome, które umożliwia organom wspólnotowym na szerokie zakreślenie swoich kompetencji w zakresie kontroli nad przyznawaną przedsiębiorcom pomocą publiczną. W konsekwencji jedynym organem, który ma prawo rozstrzygać czy dane działanie należy uznać za pomoc publiczną oraz czy jest ona zgodna z prawem unijnym jest Komisja Europejska [Piotr Marquardt, 2007, s. 31]. Obecny stan rzeczy przyczynił się do powstania licznych definicji bazujących na oficjalnych aktach prawnych i orzeczeniach Komisji Europejskiej, a zwłaszcza na art. 107 Traktatu o funkcjonowaniu Unii Europejskiej.

I. Jaźwiński [2007, s. 85] pomocą publiczną określa stosowanie przez władze publiczne w sposób selektywny wszelkich narzędzi polityki gospodarczej wobec podmiotów. Podkreśla, iż „cechą odróżniającą pomoc publiczną od innych działań interwencyjnych władz publicznych jest jej ukierunkowany charakter. Pomoc publiczna powinna mieć selektywne konsekwencje, a nie ogólne. Udzielana pomoc publiczna służy realizacji określonych celów polityki prowadzonej przez władze publiczne, np. związanych ze zmianami w strukturze sektorowej, terytorialnej i własnościowej 
gospodarki. Pomoc publiczna przysparza bezpośrednio lub pośrednio korzyści ekonomicznych i finansowych wspieranym podmiotom, stwarzając im preferencyjne i uprzywilejowane, w stosunku do rynkowych, warunki prowadzenia działalności gospodarczej”.

M. Kulesza [1996, s. 148] dodaje, iż za pomoc publiczną należy uznać „każde - w sensie ekonomicznym - przysporzenie, o charakterze nieekwiwalentnym w procesie wymiany, mające więc charakter przywileju, niezależnie od formy prawnej, w której go udzielono".

S. Dudzik [2002, s. 68] zwraca również uwagę na istotę identyfikacji źródła pochodzenia środków, gdyż za pomoc publiczną należy uznać „każde świadczenie na rzecz przedsiębiorstwa pochodzące od państwa lub ze źródeł państwowych (zwiększające przy tym wydatki lub zmniejszające przychody państwa), które przynosi temu przedsiębiorstwu korzyść, jakiej nie mogłoby uzyskać w ramach normalnej działalności gospodarczej”. Definicję silnie zbliżoną do S. Dudzika prezentują również F. Emmert i M. Morawiecki [2001, s. 417].

Rozwój prawa w zakresie szeroko pojmowanej pomocy publicznej przyczynił się do wypracowania stosownych instrumentów prawnych służących wyjątkowemu traktowaniu MŚP. Popieranie i kształtowanie właściwych warunków funkcjonowania MŚP znalazło się na liście priorytetów polityki gospodarczej wszystkich państw europejskich. Powodem takich działań jest niewątpliwie kluczowe znaczenie tych przedsiębiorstw w rozwoju zarówno polskiej, jak i europejskiej przedsiębiorczości.

\section{WIELKOŚĆ I STRUKTURA POMOCY PUBLICZNEJ W WIELKOPOLSCE}

Wielkopolska należy do województw o jednym z wyższych wskaźników przedsiębiorczości w Polsce, zajmuje 3 miejsce ze względu na PKB na 1 mieszkańca i charakteryzuje się niską stopą bezrobocia. Działające tu firmy w latach 2007-2012 uzyskały łącznie $11472 \mathrm{mln}$ zł pomocy publicznej (w tym MŚP $7276 \mathrm{mln}$ zł, tj. 63\%). Wielkość udzielonej pomocy rosła od roku 2007 aż do 2010, po czym uległa obniżeniu o 1\% w roku 2011 w porównaniu do 2010 (w sektorze MŚP spadek wyniósł 19\%). 


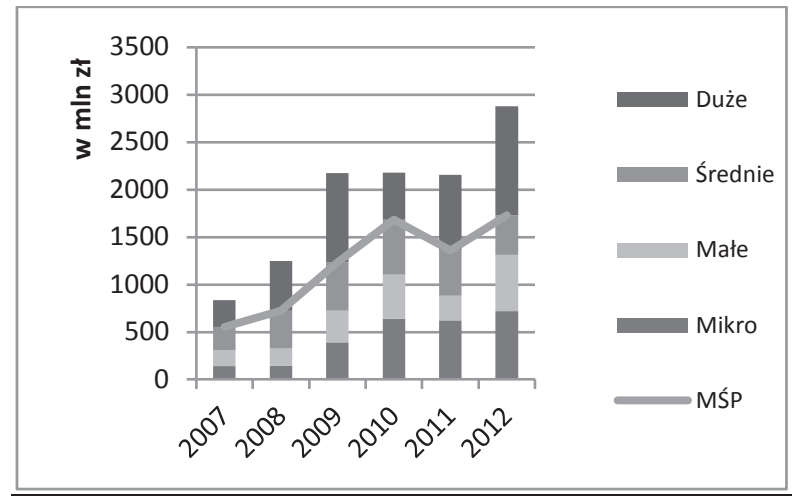

Wykres 1. Wartość udzielonej nominalnej pomocy publicznej według wielkości przedsiębiorstwa w Wielkopolsce w latach 2007-2012

Źródło: Opracowanie własne na podstawie UOKiK.

Przeciętna wartość udzielonej pomocy publicznej w Wielkopolsce była silnie zróżnicowana pomiędzy poszczególnymi grupami wielkości przedsiębiorstw. W latach 2007-2012 w województwie wielkopolskim najniższą przeciętną wartość pomocy publicznej przyznano mikroprzedsiębiorstwom (w kwocie około 31 tys. zł). Małe przedsiębiorstwa otrzymały w tym okresie niemal dwukrotnie wyższą kwotę (53 tys. zł), podczas gdy średniej wielkości podmioty blisko 14-krotność kwoty otrzymanej przez mikroprzedsiębiorstwa.

Tabela 1. Przeciętna wartość udzielonej nominalnej pomocy publicznej (w zł) według wielkości przedsiębiorstwa w Wielkopolsce w latach 2007-2012

\begin{tabular}{|c|c|}
\hline Wielkość przedsiębiorstwa & $\begin{array}{c}\text { Przeciętna wartość } \\
\text { udzielonej nominalnej pomocy publicznej }\end{array}$ \\
\hline duże & 731540 \\
\hline średnie & 423629 \\
\hline małe & 53218 \\
\hline mikro & 30630 \\
\hline
\end{tabular}

Źródło: Opracowanie własne na podstawie UOKiK.

Liczba beneficjentów otrzymujących pomoc publiczną w województwie wielkopolskim wzrastała w latach 2007-2012, z wyjątkiem roku 
2011. Jednocześnie następowała zmiana struktury wśród beneficjentów pomocy. Rósł udział mikroprzedsiębiorstw (z 52\% w roku 2007 do 71\% w 2012 roku) przy jednoczesnym spadku udziału przedsiębiorstw innych klas wielkości. W 2012 roku odnotowano największą liczbę beneficjentów pomocy publicznej (wynoszącą 29 tys.), z czego 71\% stanowiły mikroprzedsiębiorstwa, małe $23 \%$, a średnie firmy $4 \%$ wszystkich beneficjentów.

W latach 2007-2012 najczęściej stosowano formy pomocy należące do grupy A (dotacje, ulgi). Stanowiły one $85 \%$ całkowitej wartości pomocy, a beneficjenci należący do MŚP skorzystali z $66 \%$ kwoty przyznanej w tej formie. „Miękkie kredytowanie” (odroczenia terminu płatności, rozłożenia na raty należności, pożyczki preferencyjne) należące do grupy $\mathrm{C}$ stanowiło $7 \%$ całkowitej pomocy i zaledwie 50\% tej kwoty została skierowana do MŚP.

Pomoc publiczna dla małych i średnich przedsiębiorstw należy w teorii ekonomii do zagadnień bardzo kontrowersyjnych. Podkreśla się, że ingerencja państwa ogranicza mechanizm rynkowy, odbywa się kosztem innych podmiotów oraz narusza reguły konkurencji będącej kołem zamachowym w gospodarce rynkowej. Głównymi kontrargumentami dla takiego podejścia do pomocy publicznej jest podkreślanie znaczenia sektora MŚP w gospodarce, w tworzeniu PKB, w kreacji nowych miejsc pracy, ich elastyczności w zakresie dostosowania się do zmieniającego się popytu oraz wpływu na przedsiębiorczość lokalną.

\section{ODDZIAEYWANIE POMOCY PUBLICZNEJ NA KONDYCJĘ EKONOMICZNĄ MŚP W WIELKOPOLSCE}

Dane, stanowiące podstawę przeprowadzonych badań empirycznych, pochodziły z dwóch niezależnych źródeł i obejmowały przedsiębiorstwa należące do sektora MŚP w Wielkopolsce.

Pierwszym źródłem danych była baza danych Urzędu Ochrony Konkurencji i Konsumentów (UOKiK) - organu odpowiedzialnego za monitorowanie pomocy publicznej w Polsce.

Drugie źródło danych stanowiły mikro dane o sytuacji finansowej przedsiębiorstw, pochodzące z lokalnych baz danych urzędów skarbowych w Wielkopolsce, gromadzonych przez system Poltax służący rejestracji i przetwarzaniu danych pochodzących z deklaracji i informacji składanych przez przedsiębiorców organom podatkowym.

Z uwagi na zasadnicze różnice dotyczące sposobu, jak i celów gromadzenia informacji integracja danych możliwa jest za pomocą odpo- 
wiednich algorytmów odnoszących się do pośrednich tablic technicznych (sprowadzających dane do porównywalności) oraz utrzymujących nie identyfikowalność (anonimowość podmiotów). Za pomocą pośrednich tablic technicznych nastąpiło połączenie baz danych UOKiK przekazanych w systemie jawnym w urzędach skarbowych w Wielkopolsce, a następnie przekazanie, po anonimizacji danych beneficjentów (podatników), przez urzędy skarbowe w postaci umożliwiające ich dalsze przetwarzanie i dokonanie analizy mikro-danych.

W badaniu uwzględniono wszystkie podmioty należące do sektora MŚP z uwzględnieniem grup wielkości przedsiębiorstw otrzymujących pomoc publiczną. Ponadto wyłączono $\mathrm{z}$ analizy podmioty prowadzących działalność w ramach sekcji: A, O, P, Q, R, U oraz tych, dla których nie istniały pełne dane umożliwiające przeprowadzenie szczegółowej analizy. Na podstawie zebranych danych dokonano analizy wyników ekonomicznych przedsiębiorstw otrzymujących i nieotrzymujących pomoc publiczną w Wielkopolsce.

Analiza wykazała, że w latach 2007-2012 przeciętne przychody ze sprzedaży przypadające na 1 mikroprzedsiębiorstwo otrzymujące pomoc publiczną wzrastały, za wyjątkiem 2009 roku, w którym nastąpił spadek o 6\% (do 470 tys. zł) w stosunku do roku poprzedniego. Beneficjenci pomocy ograniczyli wydatki na środki trwałe jedynie w 2009 (o 13\%) oraz w 2012 roku (o 24\%).

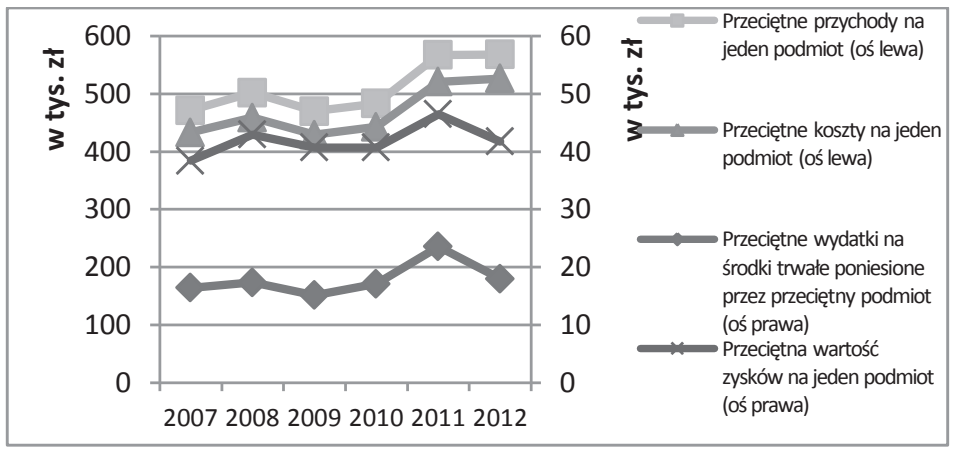

Wykres 2. Przeciętne wartości przychodów, kosztów, zysków oraz wydatków na środki trwałe uzyskiwane przez mikroprzedsiębiorstwa będące beneficjentami pomocy publicznej w Wielkopolsce w latach 2007-2012

Źródło: opracowanie własne na podstawie danych z Urzędów Skarbowych w Wielkopolsce i danych UOKiK. 
Analizowane wartości oraz ich dynamika kształtowały się odmiennie w przypadku mikroprzedsiębiorstw nieotrzymujących pomocy publicznej.

Zarówno przychody, koszty, jak i zyski tych przedsiębiorstw malały w latach 2007-2012, wyjątek stanowił rok 2008 (wzrost o odpowiednio $1 \%, 1 \%, 5 \%$ w roku 2008) oraz 2011 (wzrost o odpowiednio 4\%, 5\%, 2\% w roku 2011).

Ponadto w całym badanym okresie przedsiębiorstwa ograniczały swoje przeciętne wydatki na środki trwałe (poczynając od roku 2008 wynosiły one $5 \%, 9 \%, 11 \%$ oraz $8 \% \mathrm{w}$ roku $2012 \mathrm{w}$ stosunku do roku poprzedniego).

Obie grupy mikroprzedsiębiorstw różnią się nie tylko opisanym już kierunkiem i dynamiką zmian poszczególnych wartości, ale również ich przeciętnym poziomem we wszystkich badanych latach. Beneficjenci pomocy odznaczają się wyższą przeciętną wartością przychodów oraz kosztów przy jednocześnie niższym poziomie zysków, na co w dużej mierze miały wpływ wyższe wydatki na środki trwałe, które były wyższe w przypadku beneficjentów pomocy w kolejnych latach o 40\% (2007 rok), 56\%, $49 \%, 88 \%, 189 \%$ i $139 \%$ w roku 2012.

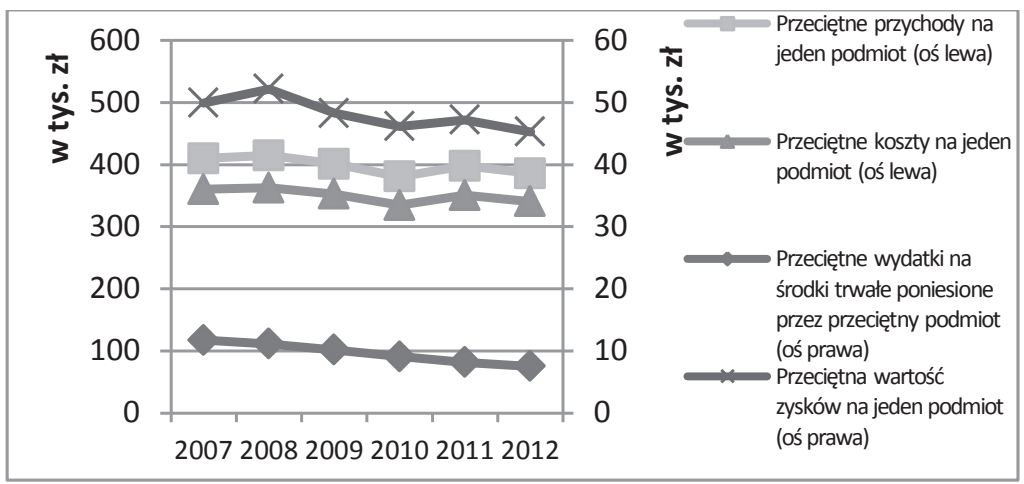

Wykres 3. Przeciętne wartości przychodów, kosztów, zysków oraz wydatków na środki trwałe uzyskiwane przez mikroprzedsiębiorstwa niebędące beneficjentami pomocy publicznej w Wielkopolsce w latach 2007-2012

Źródło: opracowanie własne na podstawie danych z Urzędów Skarbowych w Wielkopolsce i danych UOKiK.

W latach 2007-2012 przeciętne przychody ze sprzedaży oraz koszty uzyskiwane przez małe przedsiębiorstwo otrzymujące pomoc publiczną wzrastały, za wyjątkiem 2008 roku, w którym nastąpił spadek w stosunku do roku poprzedniego o $21 \%$ (obu wartości). 
Beneficjenci pomocy zwiększali w latach 2007-2010 wydatki na zakup środków trwałych, nie działo się to jednak w jednakowym tempie (najwyższy wzrost w porównaniu do roku poprzedniego miał miejsce w 2009 roku o 25\%). W 2011 i 2012 roku małe przedsiębiorstwa redukowały wydatki na środki trwałe o kolejno 15\% i 11\%, osiągając ostatecznie poziom 112 tys. zł., co stanowiło kwotę wyższą od wydatków w roku 2007 o 5\%.

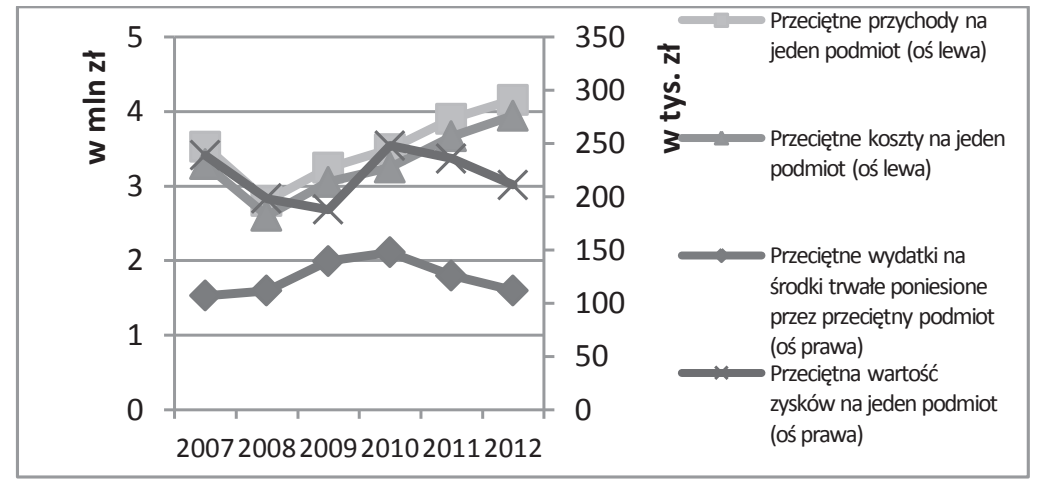

Wykres 4. Przeciętne wartości przychodów, kosztów, zysków oraz wydatków na środki trwałe uzyskiwane przez małe przedsiębiorstwa będące beneficjentami pomocy publicznej w Wielkopolsce w latach 2007-2012

Źródło: opracowanie własne na podstawie danych z Urzędów Skarbowych w Wielkopolsce i danych UOKiK.

Przychody oraz koszty w przedsiębiorstwach małych niebędących beneficjentami pomocy publicznej regularnie rosły (o 4\% rocznie), za wyjątkiem roku 2009, w którym koszty wzrosły o $1 \%$ przy niezmienionych przychodach oraz w roku 2011, w którym wzrost obu wartości sięgnął 8\%.

W całym badanym okresie przedsiębiorstwa ograniczały swoje przeciętne wydatki na środki trwałe, wyjątek stanowiły lata 2010 (wzrost o $10 \%$ ) oraz rok 2012 (wzrost o 5\%).

Obie grupy małych przedsiębiorstw różnią się dynamiką i kierunkiem zmian badanych wartości. Za wyjątkiem roku $2008 \mathrm{w}$ obu grupach następował wzrost przychodów oraz kosztów, jednakże podmioty otrzymujące wsparcie w postaci pomocy publicznej przejawiały ponad dwukrotnie wyższą dynamikę ich zmian.

Beneficjenci pomocy aż do 2010 roku zwiększali środki zaangażowane w zakup środków trwałych ograniczając je w dwóch ostatnich latach. Przedsiębiorstwa które znalazły sie w drugiej spośród analizowanych 
grup ograniczały wydatki na środki trwałe w sposób regularny (za wyjątkiem roku 2010 i 2012).

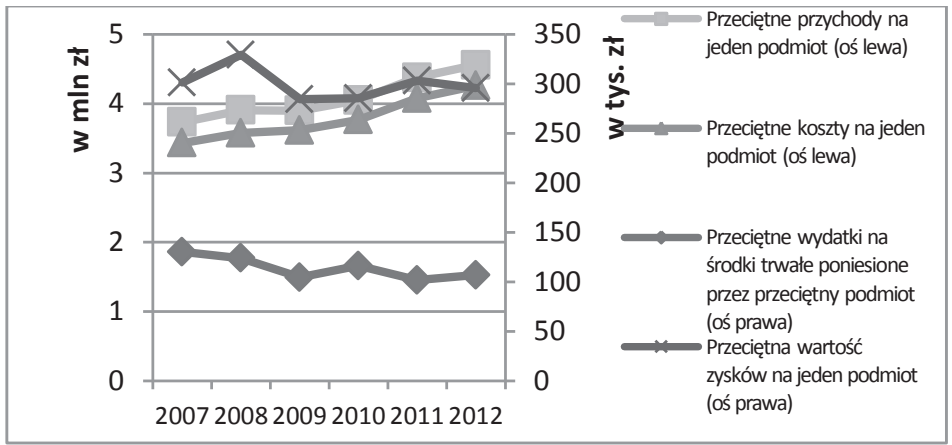

Wykres 5. Przeciętne wartości przychodów, kosztów, zysków oraz wydatków na środki trwałe uzyskiwane przez małe przedsiębiorstwa niebędące beneficjentami pomocy publicznej w Wielkopolsce w latach 2007-2012

Źródło: opracowanie własne na podstawie danych z Urzędów Skarbowych w Wielkopolsce i danych UOKiK.

W latach 2007-2012 przeciętne przychody ze sprzedaży oraz koszty uzyskiwane przez średnie przedsiębiorstwo otrzymujące pomoc publiczną wzrastały, zjawisko to było jednak intensywniejsze w latach 2009-2012 w przypadku kosztów (odpowiednio o 1 p.p., 1 p.p., 3 p.p.) niż przychodów. Maksymalny wzrost tych wartości w stosunku do roku poprzedniego nastąpił w roku 2010 (wzrost przychodów o 29\% i kosztów o 30\%).

Beneficjenci pomocy angażowali w kolejnych latach przeciętnie większe kwoty pieniężne na zakup środków trwałych. Wyjątek stanowił rok 2008 (6\%) i 2012, w którym obniżono wydatki aż o 43\% w stosunku do roku poprzedniego.

W przypadku średnich przedsiębiorstw nieotrzymujących pomocy wyraźny kierunek zmian jest powiązany ze względnie stabilną i niską dynamiką. Przychody oraz koszty w całym badanym okresie ulegają wzrostom, a dynamika kosztów przekracza o 1 p.p. dynamikę przychodów w roku 2009 i 2011.

W 2007 roku wszystkie analizowane wartości średnie były o około 5\% wyższe w przypadku podmiotów niekorzystających z pomocy publicznej, jednakże w latach kolejnych zaobserwowano znaczną różnicę $\mathrm{w}$ dynamice zmian analizowanych czynników. 


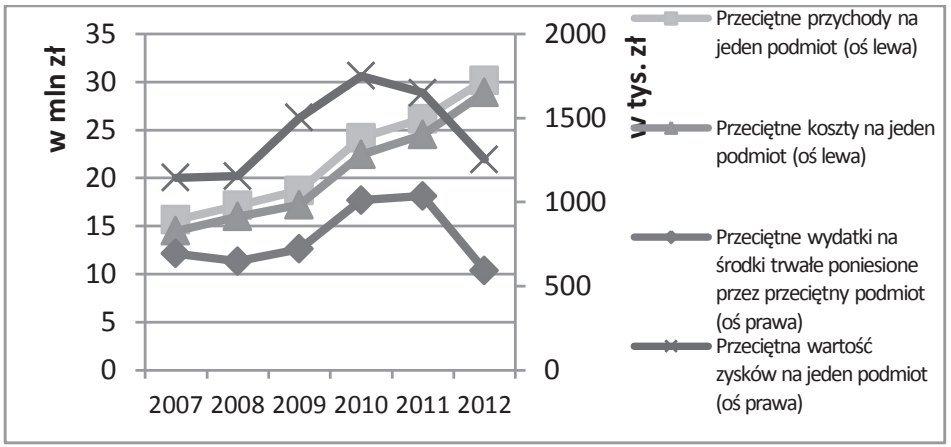

Wykres 6. Przeciętne wartości przychodów, kosztów, zysków oraz wydatków na środki trwałe uzyskiwane przez średnie przedsiębiorstwa będące beneficjentami pomocy publicznej w Wielkopolsce w latach 2007-2012

Źródło: opracowanie własne na podstawie danych z Urzędów Skarbowych w Wielkopolsce i danych UOKiK.

W obu grupach przeciętne przychody i koszty ulegały wzrostom, jednak to w przypadku beneficjentów pomocy dynamika zmian była wyższa.

Beneficjenci pomocy publicznej w pierwszych dwóch latach przeznaczali przeciętnie mniejsze kwoty na zakup środków trwałych niż przedsiębiorstwa jej nieotrzymujące, zmieniło się to w latach 2009-2011, w których wydatki wzrosły i były odpowiednio wyższe od wartości w drugiej grupie o 16\%, 40\% i 50\%. Znaczny spadek inwestycji wśród beneficjentów nastąpił w roku 2012 osiągając ostatecznie poziom niższy o 12\% w stosunku do podmiotów niekorzystających z pomocy publicznej.

Analiza kształtowania się wybranych wyników finansowych przedsiębiorstw sektora MŚP w latach 2007-2012 wykazała istnienie związku pomiędzy dynamiką zmian badanych wartości, a faktem otrzymywania pomocy publicznej przez przedsiębiorstwa.

W latach 2007-2010 następował wzrost wartości nominalnej pomocy publicznej wśród przedsiębiorstw zaliczonych do kategorii mikro-, małych i średnich przedsiębiorstw. Bez względu na wielkość przedsiębiorstw wśród beneficjentów pomocy publicznej zauważyć można wzrost sprzedaży, choć dla poszczególnych kategorii $\mathrm{w}$ różnym tempie, jednakże wyższym w porównaniu do przedsiębiorstw nieotrzymujących pomocy publicznej. 


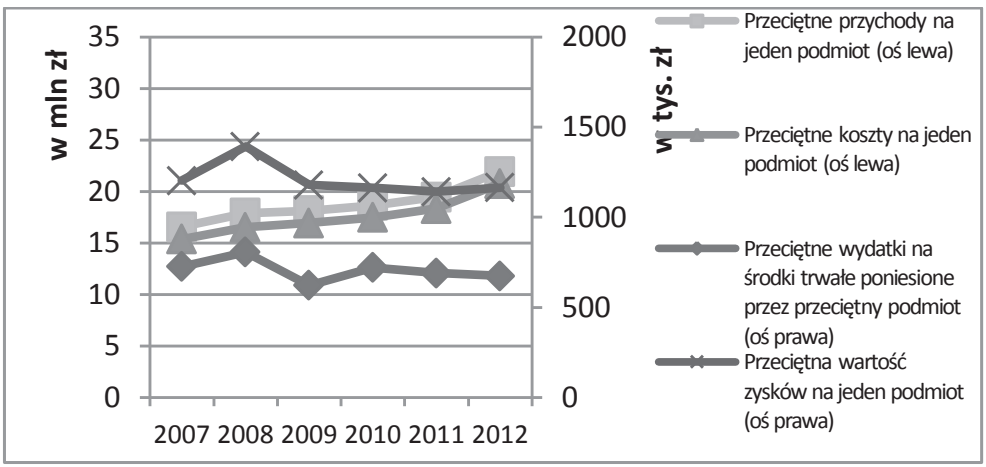

Wykres 7. Przeciętne wartości przychodów, kosztów, zysków oraz wydatków na środki trwałe uzyskiwane przez średnie przedsiębiorstwa niebędące beneficjentami pomocy publicznej w Wielkopolsce w latach 2007-2012

Źródło: opracowanie własne na podstawie danych z Urzędów Skarbowych w Wielkopolsce i danych UOKiK.

W okresie, w którym następował wzrost łącznej wartości udzielonej pomocy publicznej w grupie beneficjentów następował wzrost wydatków na zakup środków trwałych, który zakończył się silnym spadkiem w roku 2012 (dla małych przedsiębiorstw spadek rozpoczął się rok wcześniej). Stanowić to może reakcję na sygnały z 2011 r. o spadku wielkości pomocy publicznej oraz na zakończenie przez część przedsiębiorców wcześniejszych planów inwestycyjnych.

Akcja inwestycyjna wśród beneficjentów pomocy publicznej wiązała się z ograniczeniem zysków, a nawet przejściowymi stratami, jednak jednocześnie obniżała obciążenia podatkowe prowadzonej działalności poprzez zmniejszenie podstawy opodatkowania podatkiem dochodowym, a przez to zatrzymaniem większej części przychodów w firmie.

\section{PODSUMOWANIE}

Przedsiębiorstwo - aby zaistnieć, działać i przetrwać - musi rozwijać się i doskonalić, to jednak wymaga odpowiednich środków finansowych. Swoje potrzeby finansowe może pokrywać ze źródeł wewnętrznych - wygospodarowanych w przedsiębiorstwie - oraz zewnętrznych, znajdujących się poza przedsiębiorstwem. Mikro-, małe i średnie przedsiębiorstwa mają często ograniczony dostęp do zewnętrznych źródeł finansowania, a te, do 
których mają dostęp pozostają wciąż drogą formą finansowania działalności. Jednocześnie $\mathrm{w}$ dobie globalizacji i innowacji środki finansujące rozwój przedsiębiorstwa są niezbędne, aby dotrzymać kroku konkurencji. Alternatywną formę pozyskania poszukiwanych środków stanowi pomoc publiczna.

Analiza danych o pomocy publicznej i wynikach beneficjentów wskazuje na następujące współzależności:

1. Wielkość pomocy publicznej bezpośrednio oddziałuje na decyzje inwestycyjne, tzn. bezpośrednio po okresie uruchomienia środków pomocowych w badanej grupie następował wzrost zakupu środków trwałych, a zmniejszenie wielkości pomocy, co miało miejsce w 2011 r., wpływa natychmiast na wycofanie się z akcji inwestycyjnej;

2. Udzielona pomoc publiczna wpływa na zwiększenie wartości sprzedaży wśród jej beneficjentów, jednocześnie dynamika tych wzrostów pozostaje na wyższym poziomie niż w grupie przedsiębiorstw nieotrzymujących pomocy.

3. Pomoc publiczna nie wpływa jednakowo na wyniki finansowe przedsiębiorstw należących do różnych grup wielkości.

Ponad $85 \%$ udzielonej pomocy w badanym okresie stanowiły dotacje. Ocena czy rezultatem jednorazowego zasilenia finansowego o charakterze bezzwrotnym może być trwała poprawa kondycji finansowej przedsiębiorstw i brak późniejszej konieczności wsparcia ze środków publicznych, stanowi klucz do podejmowania decyzji o formach jej udzielania.

\section{LITERATURA}

Dudzik S., Pomoc państwa dla przedsiębiorstw publicznych w prawie Wspólnoty Europejskiej, Zakamycze 2002.

Emmert F., Morawiecki M., Prawo europejskie, Warszawa-Wrocław 2001.

Jaźwiński I., Pomoc publiczna dla przedsiębiorstw, Zeszyty Naukowe Uniwersytetu Szczecińskiego, Szczecin 2007, nr 453.

Kulesza M., Pomoc publiczna dla przedsiębiorstw w RP. Uwagi wstępne na tle postanowień Traktatu Rzymskiego i Uktadu o stowarzyszeniu, w: Wspótczesne problemy administracji publicznej, „Studia Iuridica” Warszawa 1996, t. 32.

Marquardt P., Pomoc publiczna dla matych i średnich przedsiębiorstw, Wydawnictwo LexisNexic, Warszawa 2007. 
Misiąg F., Pomoc publiczna dla małych i średnich przedsiębiorstw. Mity i rzeczywistość, PWE, Warszawa 2005.

Niemyska E., Pomoc publiczna dla małych i średnich przedsiębiorstw $w$ okresie dekoniunktury gospodarczej, Polska Agencja Informacji i Inwestycji, Warszawa 2008.

Postuła I., Pomoc publiczna dla przedsiębiorstw, Studia i Materiały Warszawa 2005, nr 1/2005, Wydział Zarządzania UW.

Szpringer W., Równość konkurencji w gospodarce rynkowej. Aspekty instytucjonalne, Warszawa 1996.

Ustawa z 27 lipca 2002 roku o warunkach dopuszczalności i nadzorowaniu pomocy publicznej dla przedsiębiorców (Dz.U. 2002, nr 141, poz. 1177 z późn. zm.).

Zoltan J. Acs, Young B., Small and Medium Sized Enterprises in the Global Economy, University of Maryland 1995.

\title{
PUBLIC AID AS SOURCE OF FUNDING SME WITH THE WIELKOPOLSKA EXAMPLE.
}

\begin{abstract}
Nowadays public aid is a very important tool of funding, allowing to happen many different investment plans for SME. Article shows strong dependency between amount of income, costs, profits, expenses on fixed assets and value of given aid but for different categories of SME in various pace. Important occurrence is connected with delay in time of assistance effects. It shows how strong is connection between growth of enterprises and given assistance, on the other side the ability of keeping high place on the market.
\end{abstract}

Keywords: public aid; grants; income; profit; cost; expenses on fixed assets. 